\title{
Cardiocutaneous Fistula Secondary to Left Ventricular Pseudo-Aneurysm Rupture
}

\author{
Feridoun Sabzi, Atefeh Asadmobini, Neda Raofi, Mohammad Javad Kademi \\ Cardiovascular Research Center, Kermanshah University of Medical Sciences, Kermanshah, Iran
}

Corresponding author: Atefeh Asadmobini, Cardiovascular Research Center, Kermanshah University of Medical Sciences, Kermanshah, Iran; E-mail: a.asadmobini@gmail.com

Received: 17 June 2020 • Accepted: 14 July 2020 Published: 30 June 2021

Citation: Sabzi F, Asadmobini A, Raofi N, Kademi MJ. Cardiocutaneous fistula secondary to left ventricular pseudo-aneurysm rupture. Folia Med (Plovdiv) 2021;63(3):457-9. doi: 10.3897/folmed.63.e55544.

\begin{abstract}
Infection of the suture line after left ventricular aneurysm repair with formation of cardiocutaneous fistula $(C F)$ is a rare but important complication. We report an unusual case of CF due to staphylococcus infection six months after repair of a myocardial rupture secondary to dehiscence repair. The only clinical manifestations were a cutaneous fistula and sternal wound discharge. Upon primary repair of pseudoaneurysm, our patient's postoperative course was uneventful. Postoperative echocardiogram revealed no residual cavity, pseudoaneurysm or valvar endocarditis.
\end{abstract}

\section{Keywords}

cardiac surgery, cardiocutaneous fistula, heart aneurysm, myocardial rupture, staphylococcus infection, Teflon pledgets, suture line

\section{INTRODUCTION}

Sternal dehiscence occurs in $1.5 \%$ of subjects who undergo heart surgery. Chest tube drainage of the mediastinum, sternal table debridement and early sternal closure are preferred in the management of these patients. During redo-sternotomy and dissection of mediastinal adhesion to surrounding tissue, massive bleeding develop in $0.08 \%$ of subjects from a tear of the right atrial wall, free wall of the right ventricle or left ventricle. ${ }^{1}$ Sternal infection is a serious problem that occurs after cardiac surgery at the rate of $1 \%$ to $4 \% .^{2}$ Treatment is always done in the operating room with low complication rate; however, life-threatening bleeding can occur after infection. ${ }^{3}$

Infection of the foreign bodies such as Gortex, Dacron patch, and Teflon pledgets on the heart suture lines after myocardial rupture repair is an extremely rare phenomenon. This complication presents with rupture, pseudoaneurysm, and a fistulous tract connecting heart to the skin. ${ }^{4}$
We report an unusual case of cardiocutaneous fistula due to staphylococcus infection six months after repair of a myocardial rupture secondary to dehiscence repair.

\section{CASE REPORT}

A 53-year-old man with a history of coronary artery bypass graft presented to emergency care service with catastrophic bleeding from the fistula site without any time for diagnostic work-up. The only clinical manifestations were a cutaneous fistula and sternal wound discharge. He had undergone left ventricular rupture repair six months before the event. Following resuscitation and history taking concerning previous dehiscence repair and left ventricle rupture, the diagnosis was established. The patient was referred to the operating theatre. Temporary control of the bleeding was achieved with digital and full palm pressure on the fistula tract in the 4th intercostal space in the left parasternal location. Left coast-sternal junction in the 4th intercostal space was eroded by large pulsating pseudoaneurysm drained by small skin fistula. This 
was followed by the immediate repair of the fistula tract by the approximating edge of the fistula crater by nylon sutures (Figs 1, 2). It extended through the left ventricle suture line rupture and drained at the parasternal wall, like a fistula to the skin. Sternotomy revealed a well-healed sternal bone without evidence of osteomyelitis but showed a soft-tissue mass adjacent to the left sternal edge. A deep hypothermic $C P B$ arrest was performed and the pseudoaneurysm was opened. Previous Teflon pledgets, fistulous tract, and infected clot were surgically removed. This was followed by the immediate repair of the fistula tract by the approximating edge of the fistula crater by nylon sutures. Microbiology of the infected clot revealed staphylococcus aureus infection. Upon primary repair of pseudoaneurism, our patient's postoperative course was uneventful. Postoperative echocardiogram revealed no residual cavity or pseudoaneurysm or valvular endocarditis (Fig. 3).

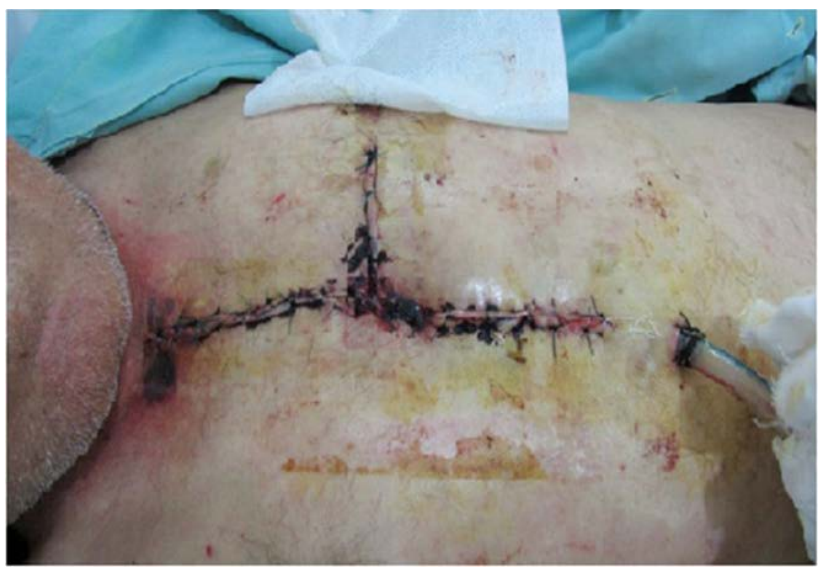

Figure 1. Combined thoracotomy and sternotomy to access the pseudoaneurysm.

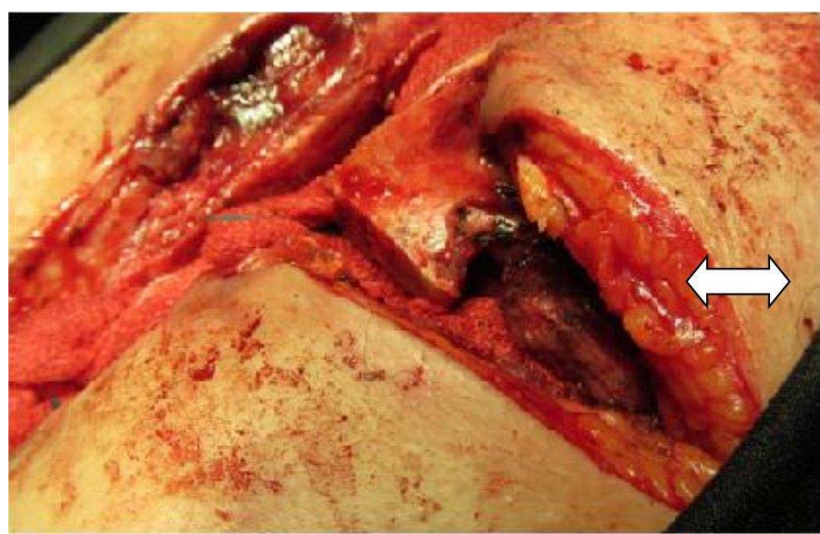

Figure 2. Sternal edge necrosis in costosternal junction (twohead white arrow).

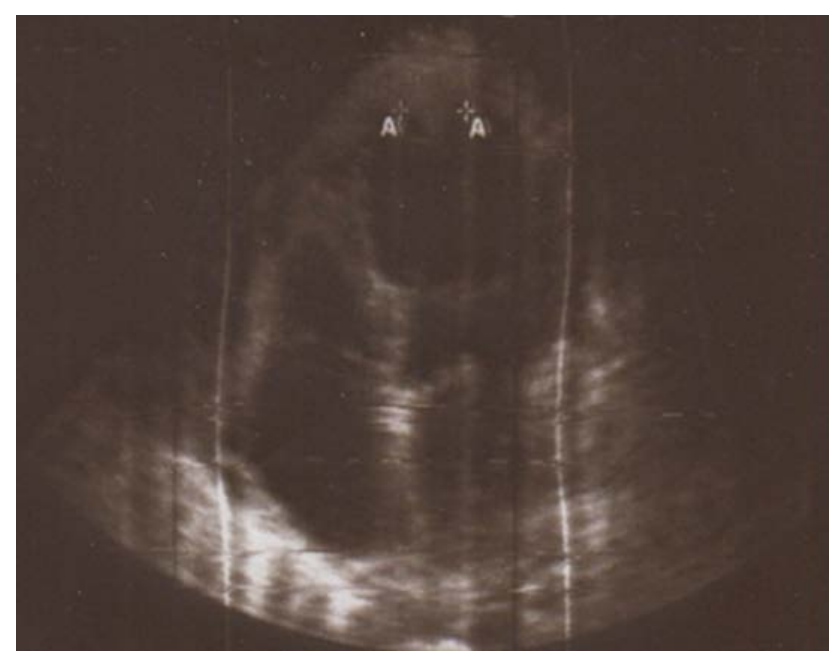

Figure 3. The suture line in the left ventricular free wall after operation.

\section{DISCUSSION}

Foreign bodies are used to reinforce the myocardial suture line or to cover the myocardial defect to reduce tension on the suture line. The infection can either spread locally or cause bacteremia and sepsis. Deuvaert et al..$^{5}$ revealed that with local extension, or rupture, a pseudoaneurysm can form and exit either at the bronchial tree (cardiobronchial fistula) or through the chest wall and skin (cardiocutaneous fistula). In essence, it can be incurable with antibiotics alone and then the infection re-manifest itself with external discharge from the left anterior chest wall. In McCormick's study, thirty-one cases of suture line infections following cardiac surgery have been reported. ${ }^{6}$ Of these, 18 were true cardiocutaneous fistulae draining at the chest wall. Myocardial-cutaneous fistula was observed only in two patients. Mean time to the presentation of CF was 16 months from the original surgery with a wide range ( 0.5 to 84 months) of time. Although microorganisms with low virulence such as Staphylococcus epidermidis, Pepto streptococcus sp, etc, are commonly isolated, more aggressive pathogens (such as Staphylococcus aureus) have also been reported. ${ }^{7}$ Sterile inflammatory reaction resulting in fistula formation and secondary colonization has also been suggested. Diagnosis is usually delayed because of the chronicity and indolent characteristics of the infection. Computed tomography (CT) and magnetic resonance imaging have a high diagnostic yield in non-emergent cases. Management of CF requires surgical excision of the tract and removal of the infected foreign bodies. Oral antimicrobial treatment will not eradicate the infection.

The clinical manifestations of cutaneous fistula or sternal wound discharge after repair of a ventricle rupture can hide the presence of ventricular pseudoaneurysm. 


\section{REFERENCES}

1. Dimitrakakis G, Kornaszewska M, Deglurkar I. Cardiocutaneous fistula 15 years postcardiac surgery: A real challenge. J Card Surg 2020; 35(5):1119-21.

2. Yellin A, Refaely Y, Paley M, et al. Major bleeding complicating deep sternal infection after cardiac surgery. J Thorac Cardiovasc Surg 2003; 125(3):554-8.

3. Thorsteinsson DT, Valsson F, Geirsson A, et al. Major cardiac rupture following surgical treatment for deep sternal wound infection. Interact Cardiovasc Thorac Surg 2013; 16(5):708-9.
4. Danias PG, Lehman T, Kartis T, et al. Cardiocutaneous fistula. Heart 1999; 81:325-26.

5. Deuvaert FE, Wellens F, De Paepe J, et al. Cardiocutaneous fistula after left ventricular aneurysm repair. Case report and review of the literature. J Cardiovasc Surg (Torino) 1984; 25(6):560-2.

6. McCormick JR, Berger RL, Davis Z. Management of cardiocutaneous fistulas. J Thorac Cardiovasc Surg 1981; 81(2):317-8.

7. Looser KG, Allmendinger PD, Takata H, et al. Infection of cardiac suture line after ventricular aneurysmectomy. Report of two cases. J Thorac Cardiovasc Surg 1976; 72:280-1.

\title{
Кожно-сердечно-сосудистая фристула, вторичная по отношению к разрыву псевдоаневризмы левого желудочка
}

\author{
Феридун Сабзи, Атефех Асадмобини, Неда Раофи, Мохамед Джавад Кадеми \\ Исследовательский центр сердечнососудистых заболеваний, Керманшахский университет медиинских наук, Керманшах, Иран
}

Адрес для корреспонденции: Атефех Асадмобини, Исследовательский центр сердечнососудистых заболеваний, Керманшахский университет медицинских наук, Керманшах, Иран; E-mail: a.asadmobini@gmail.com

Дата получения: 17 июня 2020 Дата приемки: 14 июля 2020 Дата публикации: 30 июня 2021

Образец цитирования: Sabzi F, Asadmobini A, Raofi N, Kademi MJ. Cardiocutaneous fistula secondary to left ventricular pseudoaneurysm rupture. Folia Med (Plovdiv) 2021;63(3):457-9. doi: 10.3897/folmed.63.e55544.

\section{Резюме}

Инфекция линии шва после восстановления аневризмы левого желудочка с образованием кожно-сердечно-сосудистой фистулы (КССФ) - редкое, но важное осложнение. Мы сообщили о необычном случае КССФ в результате стафилококковой инфекции через шесть месяцев после восстановления разрыва миокарда, вторичного по отношению к восстановлению расхождения. Единственными клиническими проявлениями были кожный свищ и секрет черепной раны. При рецидиве псевдоаневризмы послеоперационное течение нашей пациентки протекало без осложнений. Послеоперационная эхокардиограмма не выявила остаточной полости, псевдоаневризмы или клапанного эндокардита.

\section{Ключевые слова}

кардиохирургия, кожно-сердечно-сосудистая фистула, аневризма сердца, разрыв миокарда, стафилококковая инфекция, тефлоновые прокладки, линия наложения швов 